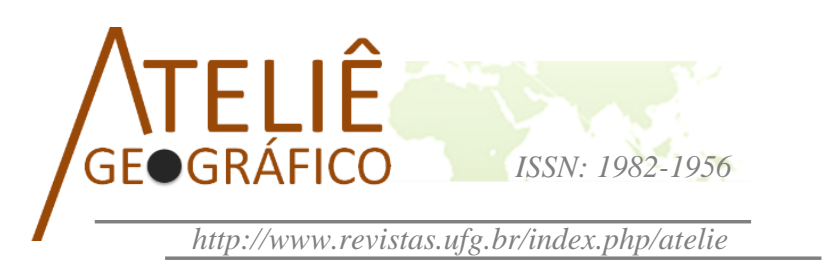

\title{
Maná, carisma e hierofania: compreensões do sagrado para a Geografia da Religião
}

\author{
Manna, charisma and hierophany: understandings of the \\ sacred for the Geography of Religion \\ Manne, charisme et hiérarchie: compréhension du sacré \\ pour la Géographie de la Religion
}

\author{
Avacir Gomes dos Santos Silva \\ Universidade Federal de Rondônia \\ avacir.santos@unir.br
}

\begin{abstract}
Resumo
O espaço não é a priori. A apreensão dele ocorre em função das espacialidades geográficas. Mas como construímos as concepções de espaço? Por que o categorizamos entre sacralidades e profanidades? Os conceitos de maná, carisma e hierofania, referentes à manifestação do sagrado, direcionam-nos para o entendimento do espaço geográfico como contributo do fenômeno religioso. Assim, nosso intuito é analisar como a formulações desses conceitos foram significativas à consolidação da Geografia da Religião. Para tanto, recorremos aos estudos comparativos dos clássicos de Émile Durkheim: "Formas elementares da vida religiosa" (2008); de Marx Weber: "Sociedade e Religião" (2009); de Mircea Eliade: "O sagrado e Profano" (2010) e de Zeny Rosendahl: "Hierópolis" (2009), entre outros. Numa primeira aproximação pontuamos a existência, a diferenciação e qualificação dos espaços sagrados e profanos defendidas por esses autores. Somente com essas classificações cognitivas o homem dos tempos primordiais conseguiu se localizar e configurar o espaço. Dessa herança passamos a formular os conhecimentos geográficos até chegarmos na Geografia da Religião.
\end{abstract}

Palavras-chave: Imagens. Espaço Sagrado. Espaço Profano. Hierofania.

\begin{abstract}
Space is not an a priori. Your apprehension occurs in function of geographical spatialities. How do we construct spatial conceptions? Why do we categorize it between sacralities and profanities? The concepts of manna, charisma and hierophany, referring to the manifestation of the sacred, direct us to the understanding of the geographical space as a contribution of the religious phenomenon. Thus, our intention is to analyze how formulations of these concepts were significant to the consolidation of the Geography of Religion. To do so, we turn to the comparative studies of Émile Durkheim's classics: "Elemental Forms of
\end{abstract}


Religious Life" (2008); of Marx Weber: "Society and Religion" (2009); of Mircea Eliade: "The sacred and Profane" (2010) and Zeny Rosendahl: "Hierópolis" (2009), among others. In a first approximation we point out your existence, the differentiation and qualification of the sacred and profane spaces defended by these authors. Only with these cognitive classifications did man of primordial times manage to locate and configure space. From now one we can formulate some geographical knowledge towards a Geography of Religion.

Keywords: Images; Sacred Space; Profane Space; Hierophany.

\section{Résumé}

L'espace n'existe pas a priori. Son appréhension a lieu en fonction des spatialités géographiques. Mais comment construisons-nous les conceptions de l'espace? Pourquoi le classons-nous en catégories de sacralités et de profanités? Les concepts de manne, de charisme et de hiérarchie, faisant référence à la manifestation du sacré, nous orientent vers la compréhension de l'espace géographique en tant que contribution du phénomène religieux. Alors, notre intention est donc d'analyser de que maniere les formulations de ces concepts ont élé significativ dans la consolidation de la Géographie de la Religion. Donc, nous nous tournons vers les études comparatives des classiques d'Émile Durkheim: "Les formes élémentaires de la vie religieuse" (2008); de Marx Weber: "Société et religion" (2009); de Mircea Eliade: "Le sacré et profane" (2010) et Zeny Rosendahl: "Hierópolis" (2009), entre autres. En première approximation, nous soulignons l'existence, la différenciation et la qualification des espaces sacrés et profanes défendus par ces auteurs. Seulement avec ces classifications cognitives que l'homme des temps primordiaux a réussi à localiser et à configurer l'espace. À partir de cette héritage, nous avons commencé à formuler les connaissances géographiques jusqu'à aboutir à la Géographie de la Religion.

Mots-clés: Images; Espace Sacré; Espace Profane; Hiérophanie ;

"Todo mundo é louco.

O senhor, eu, nós, as pessoas todas.

Por isso se carece principalmente de religião: para se desendoidecer, desdoidar" (ROSA, 2015).

\section{No começo era assim (à guisa de introdução)}

O espaço não é a priori. A apreensão desse ocorre em função das espacialidades geográficas e da condição do ser humano de postar-se no mundo. Mas, quanto tempo o homem andou ou correu sem rumo, sem direção pelas savanas africanas? Quanto tempo durou para que ele pudesse sentir a sensação de segurança na imensidão do espaço sem fim? Como o ser humano construiu as concepções de espaço? Como entendemos as categorias espaciais: em cima, embaixo, a esquerda, a direita? E como chegamos ao ponto de definir que existem espaços que são sagrados e espaços não-sagrados ou profanos?

A nossa hipótese inicial é a seguinte: a percepção espacial implicou o envolvimento de todos os sentidos; esta foi sendo moldada pela aparição da imagem da montanha. A montanha olhou para o homem e lá estava ele, parado, perplexo, paralisado, certo de sua pequenez frente a algo tão grandioso, imutável, poderoso e belo. 
Para vê-la foi preciso elevar-se. Logo, tão somente e acima dela poderia ser a morada do sagrado. Ali estava o axis mundi, onde tudo começou e onde tudo era sustentado.

Essa sensação que tomou conta do homem nos tempos primordiais nos acompanha até hoje. Frente a imensidão do mundo caótico em que vivia a montanha lhe permitiu um referencial de sacralidade. Essa imagem foi bem capturada nos versos da canção de Roberto Carlos, A montanha: "Eu vou seguir uma luz lá no alto/Eu vou ouvir uma voz que me chama/Eu vou subir a montanha e ficar/Bem mais perto de Deus e rezar" (1972), e na canção popular italiana "Bella Ciao", que ressoa pelo mundo como um grito de protesto: "Querida, adeus!/E me enterre no alto da montanha/Sob a sombra de uma bela flor/ Todas as pessoas que passarem/Me dirão: Que bela flor!"

No escrito deste artigo buscamos compreender a montanha como imagem do centro do mundo, por meio da qual nos foi possível estabelecer a ideia de um ponto fixo e a partir daí as demais noções de espacialidades. Para construção desse pensamento recorremos as contribuições de Dukheim (2008), Weber (1982, 2009, 2015), Eliade (1983, 1986, 1988, 1991, 2010) e Rosendahl (1999, 2002, 2009, 2010, 2012, 2013); os quatro grandes pilares do conhecimento religioso, que sustentarão as elaborações do pensamento geográfico quanto as definições do espaço sagrado e dos espaços profanos.

Com base nessas leituras organizamos a escrita do artigo em quatro itens a fim de compreender o pensamento desses autores sobre a definição do sagrado, espaço sagrado e profano: i) as formas elementares da vida religiosa: o sagrado em Émilie Durkheim; ii) o tipo ideal, o profeta e o carisma: o sagrado em Marx Weber; iii) as imagens micromacrocósmicas: o sagrado para Mircea Eliade e, iv) Hierópolis: o espaço sagrado em Zeny Rosendahl.

Desejamos que no percurso dessa caminhada nossas ideias se fortalecem com a força do axis mundi e, de tal forma elas possam direcionar outras tantas descobertas e (re)leituras sobre sacralidades e profanidades espaciais. Pois, a religião molda o espaço, em cada canto (lugar) com o canto (tom) da cultura.

\section{As formas elementares da vida religiosa: o sagrado em Émilie Durkheim}

Em sua obra clássica: "As formas elementares da vida religiosa", Durkheim considera o totemismo uma religião clânica, cuja essência é o maná. Essa força, presente nas tribos ${ }^{2}$ aborígenes australianas, somente se manifesta por meio da organização e coesão social. Assim: "a força religiosa não é outra coisa senão a força coletiva e anônima do clã [...], representada sob a forma do totem, "o emblema totêmico é como que o corpo visível do deus" (DURKHEIM, 1989, p. 277).

\footnotetext{
${ }^{1}$ A canção "Bella Ciao" tem sua origem no canto das trabalhadoras de plantações de arroz na Itália. Na Primeira Guerra a melodia transformou-se em uma canção de protesto. Depois foi usada como símbolo da resistência italiana contra o fascismo, durante a Segunda Guerra Mundial.

${ }^{2} \mathrm{O}$ termo tribo é considerado inadequado nas ciências humanas, por ser uma ideia generalista, que não daria conta de representar as diversidades culturais. No entanto, primitivos, aborígenes, autóctones eram empregados na obra de Durkheim para designar as sociedades australianas ágrafas estudadas por ele no início do século $\mathrm{XX}$. Assim, o uso desses termos, neste artigo fazem referências exclusivas ao pensamento durkheiniano.
} 
A religião passa ser entendida pelo grande sociólogo como um fato social. Assim, Durkheim pontua de forma incisiva: "a religião é coisa iminentemente social. As representações religiosas são representações coletivas que exprimem realidades coletivas" (1989, p. 38). Desta feita, a religião é uma representação de toda e qualquer forma de organização social. Sem coesão social não existiria religião.

A religião como fato social permite a compreensão de que as representações lógicas ou pré-lógicas também são frutos da coesão social. Desta feita,

Todas as crenças religiosas conhecidas, sejam elas simples ou complexas, apresentam um mesmo caráter comum: supõem uma classificação das coisas, reais ou ideais, que os homens representam em duas classes ou em dois gêneros opostos, designados geralmente por dois termos distintos traduzidos, relativamente bem, pelas palavras profano e sagrado (DURKHEIM, 1989, p. 68).

Para Durkheim o elemento constitutivo de toda religião é a dicotomia entre as coisas sagradas e as profanas. Essa classificação primeira separa de um lado o sagrado, aquilo que possui valor qualitativo, e do outro lado o profano aquilo de valor desqualificado. A direita e acima, por essa lógica, são pontos positivos; ao contrário em relação à esquerda e para baixo são pontos negativos.

Nesse processo de classificação das coisas sacras e profanas estão dois gêneros que não apenas são separáveis, mas que também se opõem em mundos hostis. O alcance da vida religiosa passa, necessariamente pelo abandono ou suspensão temporária da vida profana. Advém daí o conjunto de ritos, rituais, cerimônias, proibições e emulações que irá garantir a passagem ou a condição de uma vida menos significativa à outra existência mais louvável (DURKHEIM, 1989).

A diferenciação de gênero desses dois mundos: sagrado e profano implicará numa localização espacial diferenciada para ambos. A vida religiosa e a vida profana somente podem ser vividas em espaços diferenciados. A primeira deve ser excluída da segunda. Para tanto, surge a necessidade de se reservar de um espaço físico especial, onde a vida sagrada possa ser vivida em plenitude, sejam esses espaços os centros totêmicos, os templos, mesquitas, santuários ou catedrais. Para Durkheim: "essas espécies de arranjos são de tal forma indispensáveis a toda vida religiosa que as religiões mesmo as mais inferiores, não podem dispensá-los" (1989, p. 373).

Em função da separação entre coisas profanas e coisas sagradas, nas sociedades das mais primitivas as mais modernas, existiu e existirá sempre um grupo eleito para a administração das atividades sagradas: feiticeiros, adivinhos, bruxos, xamãs, curandeiros, pajés e sacerdotes ${ }^{3}$. Estes, na condição de eleitos para guardar os mistérios sacros irão determinar, para os adeptos, religiosos, devotos e fieis o que é e de que forma

${ }^{3}$ Os feiticeiros, adivinhos, bruxos, xamãs, curandeiros, pajés e sacerdotes eram os homens eleitos ou escolhidos por um ser superior, que nas sociedades primitivas, politeístas, ficavam responsáveis, exclusivamente, pelas práticas religiosas, as quais se realizavam por meio dos ritos e rituais sagrados. 
se aproximar daquilo que é sagrado. Neste sentido, a definição de religião implica um: “ sistema solidário de crenças seguintes e de práticas relativas a coisa sagrada, ou seja, separadas, proibidas" (DURKHEIM; 1989, p. 79).

Na teoria do totemismo a condição de sagrado não está restrita aos deuses ou espíritos: "qualquer coisa pode ser sagrada; um rochedo, uma árvore, uma fonte, uma pedra, uma peça de madeira, uma casa, enfim, qualquer coisa pode ser sagrada [...] há coisas sagradas de toda grau" (DURKHEIM; 1989, p. 68). Os clãs ou tribos que possuíam em comum o mesmo animal totêmico acabavam por formar os centros totêmicos. Para os quais Durkheim estabelece uma dada espacialidade: "situados a proximidade de montanhas, de fontes, de desfiladeiros onde os animais que servem de totem ao grupo se encontram em abundância [...] são certamente lugares consagrados onde o clã realizava as suas assembleias" $(1989,291)$.

Para pensamento o durkheiniano, em primeiro lugar, há coisas e espaços sagrados e profanos. Em segundo, o totem é a representação originária da religião; porém, o totem é a representação do maná. Os centros totêmicos, preferencialmente, localizavam-se próximos aos rochedos ou montanhas. Os centros, santuários e templos como espaços exclusivos e especiais da vida religiosas são elementos que nos permitem avançar para outros ensinamentos da definição dos espaços profanos e espaços sagrados. Vejamos no próximo item como o conceito de carisma, o poder extra cotidiano, elaborado por Weber nos permite ampliar tal compreensão.

\section{O tipo ideal, o profeta e o carisma: o sagrado em Marx Weber}

Para Weber a religião não passa obrigatoriamente pelo sentido de coesão social, a qual exerceria uma força externa e coercitiva sobre os indivíduos; e nem tão pouco existiria uma divindade hegemônica (totemismo, maná). Haveriam sim "religiões mundiais", "ou sistemas determinados religiosamente, de regulamentação de vida que conseguem reunir à sua volta multidões de crentes: a ética confuciana, hinduísta, budista, cristã e islamita" (WEBER, 1982, p. 310).

A análise weberiana tem como especificidades a sociedade capitalista ocidental. Diferente de Durkheim, que estudou as sociedades aborígenes australianas. Por meio de uma sociologia compreensiva, que direciona o indivíduo em primeiro plano, Weber considera que esse não é apenas condicionado pelos ditames externos, mas que ele pode sim influenciar a religião e de tal forma a própria sociedade.

Em seus estudos sobre as formas de relações de poder a igreja é compreendida por Weber como associação hierocrática, que pretende a dominação monopólica dos bens de salvação. A igreja é tida como instituição eclesiástica: "de caráter racional e de empresa que se manifesta na natureza de suas ordens e de seu quadro administrativo, de dominação territorial hierocrática e articulação territorial (em paróquia)" (WEBER, 2009, p. 35).

A concepção religiosa weberiana é vista por meio do conceito de Campo Religioso. No que diz respeito ao corpo de seus agentes, este se constitui com base em 
três protagonistas principais: os sacerdotes, os leigos e o profeta. O sacerdote compõe o grupo de funcionários que administra o sagrado ou tem influência sobre os deuses. Os leigos são aos adeptos das crenças religiosas e os consumidores dos bens religiosos. Os profetas são produtores das revelações de novos discursos e práticas religiosas.

O fundamento do poder do profeta reside no carisma. Assim: "a autoridade carismática é 'irracional'. Também é 'revolucionária' na medida em que não está ligada a ordem existente" (WEBER, 2015, p. 41). Porém, o carisma é não característica exclusiva do poder apenas nas sociedades antigas. Ele estava presente em quase todas as autoridades primitivas, com exceção daquelas onde prevalece ao pátrio poder. $\mathrm{O}$ chefe era, ou ainda é, "com frequência, simplesmente, abandonado se o êxito não lhe permanece fiel”' (WEBER; 1982, p. 208).

Uma forma equivocada de se pensar o tipo ideal é considerá-lo como um protótipo de individuo ou de um fenômeno social que se desejar alcançar. O tipo ideal é uma referência analítica, uma ferramenta utilizada pelo pesquisador, o qual por meio do levantamento de dados específicos da temática da pesquisa identifica os "ideais" não correspondentes a realidade. Este conceito será fundamental para a caracterização do profeta, visto como elemento contra hegemônico na hierarquia religiosa formada pelo sacerdote, leigo e o profeta. O profeta como tipificador ideal é o portador do carisma.

O carisma é a qualidade daquilo que está fora da vida cotidiana: animais, plantas, coisas, objetos e homens. O carisma manifesta-se por meio do dom. Este não é natural ou hereditário e nem tão pouco pode ser transferido a outrem. Assim, o termo "carisma",

[...] será entendido como referência a uma qualidade extraordinária de uma pessoa, prescindindo de que seja real, presumida ou suposta. Desse modo, a 'autoridade carismática' aludirá a um poder sobre os homens, que seja primordialmente interno ou externo, ao qual se subordina os governados em virtude de sua fé na qualidade excepcional da pessoa especifica (WEBER, 2015, p. 40).

A concepção de carisma é entendida como "um dom" inerente a uma pessoa ou objeto. Ele não é natural, caso assim fosse tantos outros o possuiriam. O indivíduo nasce com o dom, mas não recebe e nem o transfere por consanguinidade, ele também não pode ser apreendido ou ensinado. Quando por meio de atos sacerdotais se transfere o carisma para o rei ou outra pessoa a crença não será mais do receptor do carisma, mas sim da hierocracia, pelo poder de invocá-lo. Para Weber: "em sua forma genuína, a dominação carismática é de caráter especificamente extracotidiano e representa uma relação estritamente pessoal, ligada à validade carismática de determinadas qualidades pessoais e a prova destas" (2009, p.161).

Enquanto relação hierárquica o poder advindo do carismático subordina "os governados", por que existe um grupo de pessoas que irá reconhecê-lo como portador de uma missão, um poder extraordinário. Assim, na concepção weberiana do sagrado 
advém daquilo que é extraordinário (fora da ordem), por um lado; e de outro, daquele que crê nesse ser de poder extraordinário, em especifico, o detentor da boa nova.

Como a mensagem profética está no devir, também o carismático não vive para este mundo como os demais mortais: "os portadores do carisma (mestre, discípulos e seguidores) devem manter-se distantes dos laços deste mundo, das ocupações e obrigações rotineiras da vida de família (WEBER,1982, p. 286).

O caráter sagrado da boa nova está em oposição e contra o sagrado da tradição imposta pelo corpo sacerdotal, que por sua vez separa o sagrado do não-sagrado por meios técnicos e atividades que buscam uma modificação do crente de fora para dentro. A atitude revolucionária do carisma está na capacidade de transpor todos os valores, que pode ser representado no seguinte enunciado: "Está escrito, mas em verdade vos digo" (WEBER, 1982). Em suma, a adesão do poder carismático implica uma prática de fé, que ocorre de dentro para fora. O crente precisa acreditar na Boa Nova.

O carisma como poder extraordinário se aproxima da distinção da força do maná, contida na figura totêmica. Poderes extramundanos que agem sobre o mundo profano em função do homem religioso, que crê nesse poder. O totem e o carisma ${ }^{4}$ são poderes duplamente extramundanos: a força advém de um poder sagrado maior e a eficácia deles dependerá da crença interna do crente, que espera o acontecer dessa nova manifestação.

\section{As imagens micromacrocósmicas: o sagrado para Mircea Eliade}

O sagrado manifesta-se por meio de uma materialidade. A compreensão do sagrado como estrutura lógica do pensamento do homem religioso será a grande empreitada da obra de Mircea Eliade. De acordo com esse estudioso da religião, a ideia do totemismo como origem das religiões é um equívoco, pois, etnólogos e antropólogos contemporâneos a Durkheim "já tinha provado suficientemente que o totemismo não representa a mais antiga camada das religiões australianas e, mais ainda, que ele está ausente em inúmeras culturas arcaicas dispersas pelo mundo” (ELIADE, 1991, p.19).

Em suas obras em geral, e de forma especifica, em: "O sagrado e o profano" (2010), Eliade busca definir a estrutura do sagrado, por meio da apresentação de três grandes imagens: as imagens micromacrocósmicas, as imagens de abertura e as imagens iniciáticas. O Sistema de correspondência micromacrocósmicas interliga as imagens do corpo (microcósmicos) com as imagens do mundo natural (macrocósmico). A exemplo das imagens da mulher relacionada as imagens da Terra. Ambas são mães; responsáveis

\footnotetext{
${ }^{4} \mathrm{O}$ totem na concepção durkheiniana é a forma material (desenho de um animal, planta ou objeto), que representa o ancestral comum de uma família, clã ou tribo. O maná e a força sagrada que advém do totem a partir do momento em que ele mantém a coesão social do grupo.
} 
por reproduzir, gerar e cuidar da vida, antes, durante e após a morte. Outra imagem é a da coluna vertebral, que sustenta o corpo, a imagem do Axi mundi ${ }^{5}$.

Mais do que uma qualidade o espaço sagrado possui, para o homem religioso, um valor existencial e ontológico. Assim: "nada pode começar, nada se pode fazer sem uma orientação prévia, e toda a orientação implica a aquisição de um ponto fixo. É por essa razão que o homem religioso sempre se esforçou por estabelecer-se no 'Centro do Mundo"" (ELIADE, 2010, p. 26).

As imagens iniciáticas, que correspondem aos ritos de iniciação e passagem: nascimento, batismo, casamento, reprodução, morte e ressureição, constituem um dos pilares da estrutura do sagrado ao propiciar ao homem primitivo, dadas as devidas proporções, sair da condição profana para o alcance da sacralização. De acordo com Eliade, o tema do segundo nascimento enriquece ou muda radicalmente entre as diversas religiões, mas: "permanece, porém, um elemento comum, um invariante, que se poderia definir da seguinte maneira: o acesso à vida espiritual implica sempre a morte para a condição profana, seguida de um novo nascimento" (2010, p. 163).

As imagens de abertura vão desde o cosmo, a casa até o corpo humano. Segundo Eliade, essas imagens: "apresentam ou podem apresentar uma 'abertura' superior que possibilita a passagem para um outro mundo" (2010, p. 142). A esta constatação o autor enumera várias exemplificações: Creta, como aliás em toda a região do Mediterrâneo, as cavernas serviram por muito tempo de habitação, mas também, sobretudo a partir do Neolítico, de cemitérios (costume que se prolongou até os tempos modernos). Entretanto, um número bastante grande de grutas foi consagrado as diversas divindades dos povos autóctones (reconhecidos pela ancestralidade comum). Como afirma Eliade: "certos ritos, mitos e lendas, associados a esses antros prestigiosos foram mais tarde integradas as tradições religiosas dos gregos. Dicteu era celebrada por ter protegido Zeus na infância, foi nele que veio ao mundo o futuro senhor do Olimpo" (1983, p. 159).

Quando uma montanha se transforma em um espaço sagrado, não é a montanha em si, a coisa em si, que é adorada se não uma hierofania, ou seja, a montanha foi a matéria erigida para a manifestação do sagrado. Nesses espaços abertos, cavernas e montanhas, é possível ao homem religioso se comunicar com os deuses. Desta feita, as imagens de abertura moldaram a definição entre espaço sagrado e espaço profano. Esta diferenciação será marcada pelas imagens da montanha (ser imutável), que possibilitou a identificação do ponto fixo localizacional.

$\mathrm{Na}$ montanha se chega mais perto do céu. O que implica concebê-lo como morada do sagrado (em cima); o profano, morada do homem (no meio); embaixo da terra (morada dos mortos). A montanha interliga o homem religioso e a divindade. Como cantava o poeta, Raul Seixas, em tom profético: “Ói, oia o trem, vem surgindo de trás

\footnotetext{
${ }^{5}$ Axi mundi (centro do mundo) é uma expressão recorrente nas obras de Eliade como referência para centro de uma montanha ou coluna, que na compreensão do homem religioso estabelecia a comunicação entre os três mundos: o céu, terra e o mundo dos mortos.
} 
das montanhas Azuis, olha o trem/ Vê, é o sinal, é o sinal das trombetas, dos anjos e dos guardiões/ Ói, lá vem Deus, deslizando no céu entre brumas de mil megatons".

O espaço não é homogêneo. Há um espaço sagrado e há outros espaços nãosagrados. O primeiro é uno, forte, indivisível, significativo, real; nele vive-se a experiência sagrada. Em contraposição, os espaços não-sagrados são sem estrutura ou consistência, amorfos, caóticos, neles vive-se a experiência profana, que se opõe a experiência sagrada. As simbologias voltadas as representações do espaço sagrado, de acordo com Eliade são capazes de revelar,

[...] uma perspectiva em la cual las realidades heterogéneas pueden articularse en um todo o aun integrarse dentro de un 'sistema' [...] el símbolo religioso permite al hombre encontrar una certa unidad en el mundo y, al mismo tempo, descobrir su próprio destino como parte integrante de aquél” (1986, p. 130).

Para o homem religioso, das sociedades arcaicas, o espaço sagrado é o real. Ele quer e procura viver essa realidade a fim de não se perder na imensidão do caos. Como afirma, Riobaldo, o personagem de Guimarães Rosa na epigrafe deste artigo. Perto do sagrado a vida é plena, como era antes da primeira queda. $\mathrm{O}$ sonho de completude humana, o anseio por fazer parte do todo é algo que com a dessacralização do mundo passou a ter como refúgio a alma do poeta. Este desejo está expresso no poema "Meditações 17" de John Donne,

Nenhum homem é uma ilha, isolado em si mesmo; todos são parte do continente, uma parte de um todo. Se um torrão de terra for levado pelas águas até o mar, a Europa ficará diminuída, como se fosse um promontório, como se fosse o solar de teus amigos ou o teu próprio; a morte de qualquer homem me diminui, porque sou parte do gênero humano. E por isso não perguntes por quem os sinos dobram; eles dobram por ti (DONNE, 1624).

O poema acalanta o sonho cósmico de vivermos uma realidade sagrada. Esta realidade é plena de sacralidade e o religioso fará tudo que estiver ao seu alcance, por meio do sacrifício (fazer sacro), para encontrar e permanecer nesse espaço sagrado. Para o homem da sociedade arcaica: "toda experiência religiosa auténtica implica un desesperado esfuerzo por descobrir el fundamento de las cosas, la realidad última" (ELIADE, 1986, p. 119).

No pensar de Eliade o espaço sagrado implica uma hierofania; em dimensão maior uma teofania, intermediaria uma hierofania, e em dimensão menor num sinal. Por que uma pedra ou uma montanha se tornam sagradas, tendo em vista que existem milhares delas que não o são? A pedra pode ser um sinal ou uma metáfora da sacralidade. "Quem dentre vós não tiver pecado, atire a primeira pedra". A montanha pode ter sido impregnada da presença do sagrado, a exemplo da Cavernas dos Tesouros, dos Sírios. Assim, na imensidão infinda do espaço, uma parte se torna sagrada: "porque constituiu uma hierofania, ou porque possui um maná, ou porque sua forma reflecte um 
certo simbolismo, ou ainda porque comemora um acto mítico, etc.” (ELIADE, 1988, p.18).

Dessa feita, espaço sagrado é qualitativamente diferenciado do espaço profano, inerte de sacralidade. O sagrado se manifesta por meio da hierofania, para tanto, pode valer-se de pessoas, coisas, objetos, estrela ou montanha. Um espaço profano qualificase em espaço sagrado por meio dos rituais de sacros e atividades do domínio religioso.

Para o homem religioso das sociedades tradicionais o espaço sagrado constitui uma rotura na homogeneidade do espaço, esta simbolizada por uma imagem de abertura. Assim: "o homem das sociedades tradicionais só podia viver num espaço "aberto" para o alto, onde a rotura de nível estava simbolicamente assegurada e a comunicação com o outro mundo, o mundo transcendente, era ritualmente possível" (ELIADE, 2010, p. 43).

As imagens de abertura moldaram a diferenciação entre espaço sagrado e profano. Esta diferenciação será marcada pelas imagens da montanha (ser imutável), que possibilitam a identificação do ponto fixo localizacional, o centro do mundo, onde ocorria a comunicação com os três mundos: céu, terra e o inferno. Assim, foi possível identificar o espaço conhecível. A localização do ponto cotado. A imagem da montanha como axis mundi é vista: "como un polo que sostiene el cielo, une las três zonas cósmicas (el cielo, la tierra y el infierno) y al mismo tempo permite la comunicación entre el cielo y la tierra" (ELIADE, 1986, p.124).

Tudo que existe tem como espaço embrionário o centro. Para os cristãos o Paraíso onde Adão foi criado com o limo encontra-se, obviamente, no centro do Cosmo. "O Paraíso é considerado 'umbigo da Terra', e estava localizado 'numa montanha mais alta que todas as outras'. De acordo com o livro sírio A caverna dos tesouros, Adão foi criado no centro da Terra, no mesmo lugar onde, mais tarde, a cruz de Jesus se ergueria" (ELIADE, 1991, p. 40). Essa caverna está localizada na Montanha das Vitórias, onde ocorreu a aparição da Estrela, segundo os manuscritos perdidos dos Reis Magos,

E subimos a Montanha das Vitórias como estávamos acostumados a fazer [...] E novamente vimos que o céu se abria como um grande portão de glória carregando a estrela de luz em suas mãos. E eles desceram e pararam sobre o pilar de luz, e toda a montanha ficou repleta de sua luz, que não poder ser dita pela boca da humanidade" (LANDAU, 2013, p. 53).

inferno, o centro da terra e a porta do céu se encontravam no mesmo eixo, neste se dava a passagem da região cósmica para a outra. A montanha além de figuração de pilar do mundo e de canal de comunicação com as três esferas cósmicas é também o ponto central, o espaço da morada do sagrado. A partir deste a vida irradia-se, as cidades e casas são construídas. "Construa sua casa sob rochas e não sob areias". Nos ritos de orientação (geomancia) os ritos de fundação de vilas, templos, igrejas, palácios e o simbolismo das barracas, cabanas e casas se encontram a raiz da experiência do espaço sagrado e na concepção cosmológica (ELIADE, 1986). A partir da ilustração da rocha, da montanha como fortaleza, como centro das regiões habitadas, ou os microcosmos, 
[...] tem o que poderíamos chamar um "Centro", ou seja, um lugar sagrado por excelência. É nesse "Centro" que o sagrado se manifesta totalmente seja sob a forma de hierofanias elementares, como no caso dos 'primitivos' (centros totêmicos) [...] seja sob a forma mais evoluída de epifanias diretas dos deuses, como nas civilizações tradicionais (ELIADE,1991, p. 35).

Os templos, as igrejas, as catedrais serão construídas no centro, a partir do qual a cidade cresce e se desenvolve. Quando este lugar central, morada do sagrado é construída em um moro, monte, ou em uma montanha a simbologia de axis mundi fortalece ainda mais hierofanias e teofanias. "Hay innumerables ritos de orientación y mitos que los justificam, todos los cuales derivam en última instancia de la experiência del espacio sagrado. (ELIADE, 1986, p. 127).

No Brasil as construções das moradas do sagrado têm por espaços privilegiados os lugares elevados. Os quais foram palcos de hierofanias, a exemplo da Catedral Nossa Senhora Aparecida (São Paulo), ou ritualisticamente consagrados. As imagens da montanha, ou seus correlatos, centros totêmicos, altares, templos, catedrais, ligam-se a imagem primeira do mundo. De acordo com Eliade: "as colunas e os pilares compartilhavam ao que parece o simbolismo cosmológico do axis mundi, atestado já desde a pré-história" (1983, p.164).

A simbologia da montanha possui referencias de ponto, de criação e de fim do mundo. A exemplo do Cabo Finisterra (La Corunhã, Galicia, Espanha). É no alto que se localiza o céu. Os lugares mais altos e que proporcionam maior visibilidade são os escolhidos como morada do sagrado. No Rio de Janeiro, a Estátua do Cristo Redentor (no Corcovado) é considerada pela Unesco, desde 1912, como Patrimônio da Humanidade.

A montanha foi utilizada como metáfora ao poder da fé, característica do cristão. E disse-lhes Jesus: "Em verdade vos digo que, se tiverdes fé como um grão de mostarda, direis a este monte: Passa daqui para acolá, e há de passar; e nada vos será impossível" (MT-17:20). No monte Sinai Moises recebe de Deus a Lei dos Dez Mandamentos. É na Montanha que Jesus narra o mais belo Sermão. Inúmeras são as ilustrações da montanha como espaço de sacralidade no panteão do cristianismo.

As simbologias das montanhas sobrevivem até os tempos atuais com força inquestionável. Não é por menos que o rosto dos quatro presidentes, pilares da história americana: George Washington, Thomas Jefferson, Teodore Roosevelt e Abraham Lincohn foram esculpidos no Monte Rushmore (Dakota do Sul).

A história inaugurou uma nova temporalização, e, por conseguinte uma recolocação da espacialidade sagrada. Por mais que tente negar,

[...] a vida do homem moderno está cheia de mitos semiesquecidos, de hierofanias decadentes, de símbolos abandonados. A dessacralização incessante do homem moderno alterou o conteúdo de sua vida espiritual; ela não rompeu com as matrizes da 
sua imaginação: todo um refúgio mitológico sobrevive nas zonas mal controladas" (ELIADE, 1991, p. 15).

Para sobreviver o sagrado se refugiou, buscou outras paragens: a poesia, a literatura, a música, o teatro, as artes e a dança. A exemplo do mito do Paraíso Terrestre transformado na forma de "paraíso oceânico". No mundo moderno o sagrado não apenas vive, mas também está camuflado entre nós (ROHDEM, 1998).

\section{Hierópolis: o espaço sagrado em Zeny Rosendahl}

As ciências sociais, e a história em especial, promoveram a dessacralização do mundo. A geografia da religião (re)significou o sagrado e colocou-o no seu espaço original, o centro. A produção da geógrafa Zeny Rosendahl tem contribuído para este entendimento no quadro da geografia brasileira, de forma institucionalizada desde 1993, por meio da criação do Núcleo de Estudos e Pesquisas sobre Espaço e Cultura6 (NEPEC), da Universidade do Estado do Rio de Janeiro (UERJ).

Para a geografia da religião a busca pela compreensão do sagrado tem por base as contribuições de Durkheim, Marx Weber, Mircea Eliade entre outros. O primeiro postulou, a partir da ideia do totem, a existência do sagrado, vivenciada na coletividade e por meio da coesão social. Para Weber o sagrado se constitui a partir do campo religioso formado, hierarquicamente, entre sacerdotes, leigos e profetas. Para Eliade a definição do espaço sagrado implica obrigatoriamente o acontecer de uma manifestação, seja por meio de uma hierofania, teofania, ritualística ou um sinal.

Essa tríade do sagrado enquanto força social, campo religioso e hierofanias tem sido agenciada, de forma mais ou menos incisiva para os estudos e abordagens da geografia da religião. A geógrafa brasileira Rosendahl, com base nas contribuições teóricas de Eliade da estrutura do sagrado, promove a amplitude da espacialização geográfica do sagrado em seus estudos sobre as cidades sagradas, as hierópolis.

Eliade define que o sagrado se revela por meio da manifestação (hierofania, teofania, ritual, sinal) e essa pode ocorrer numa planta, bicho, pessoa ou coisa. A partir dessa especificação do sagrado, Rosendahl elabora sua teoria localizacional: "espaços sagrados são espaços qualitativamente fortes onde o sagrado se manifestou” (2002, p. 8). Tendo em vista que tanto para Durkheim, Weber como para Eliade existe uma nítida separação entre o espaço sagrado e o espaço religioso Rosendahl retrata esta dicotomia de forma mais pungente,

O sagrado se apresenta absolutamente diferente do profano, isto é, o primeiro se relaciona a uma divindade e o segundo, não. A palavra sagrado tem o sentido de separação e definição em manter separadas as experiências envolvendo uma divindade, de outras

\footnotetext{
${ }^{6}$ Neste ano o NEPEC completa 25 anos. No artigo: “Conferência NEPEC (2010), Rosendahl apresenta o quadro da produção do núcleo nesse tempo. Na sua obra intitulada "Uma procissão na geografia" (2018), a geógrafa presenteia o público com a escrita de sua trajetória nos caminhos da geografia da religião brasileira, desde de 1994, com a tese: "Porto de Caxias: espaço sagrado da Baixada Fluminense".
} 
experiências que as não envolvem, consideradas profanas (1999, p. 231).

O espaço sagrado e o espaço profano, dessa feita, diferenciam-se em função das experiências realizadas e sentidas em relação as coisas sagradas (sacrificius). Assim, o local de realizações das atividades sagradas não poderia ser o mesmo do fazeres das práticas profanas. Desta certeza, advém a existência de inúmeros ritos, rituais e cerimonias para a purificação ou sacralização dos espaços às experiências sagradas.

Ao estudar as cidades-santuários e da hierópolis Rosendahl parte da tese do sagrado como elemento de produção do espaço (2009). Esta constatação pode ser feita desde os primeiros santuários paleolíticos, os quais, muito mais que espaços segurança e de expressões artísticas, representavam para o homem religioso da época a possibilidade de compartilhar entre os demais suas práticas e crenças religiosas. Apesar da diversidade da forma dos santuários, desde os primórdios eles contém um princípio básico,

A estrutura que suporta esses centros cerimoniais pode ser uma gruta paleolítica, um centro cerimonial maias, a pirâmide, o zigurate e outros, porém todos dotados de poderes cósmicos. Tais pontos fixos e espaços sagrados de encontros periódicos ou permanentes, para os quais convergem devotos de mesma prática ou crença religiosa, ainda hoje são visitados (ROSENDAHL, 2009, p. 16).

O devoto que em romarias e procissões desloca-se até a cidade santuário carrega consigo o sentimento do homem dos tempos primordiais, a alegria do encontro com o sagrado. Rosendahl busca compreender como o sagrado, conceito plenamente religioso, irá promover a configuração ou reconfiguração do espaço, com as nuances da cultura local. Para a formulação de suas releituras a autora compreende que apesar da presença de Deus ser sentida pelo homem religioso em todo e qualquer espaço, existem espaços plenos da presença divina. Assim, uma teoria locacional, mais visível do sagrado é salutar. De forma precisa a geógrafa da religião pontua,

As interdependências e as relações funcionais entre o espaço sagrado e o espaço profano, que realizam em tempos também sagrados, permitem caracterizar o espaço profano e sugerir uma classificação em relação ao seu maior ou menor vínculo com o sagrado. Pode-se definir o espaço profano como o espaço desprovido de sacralidade, estrategicamente ao 'redor' e 'em frente' do espaço sagrado. Identificamos o espaço profano diretamente vinculado ao sagrado, o espaço profano indiretamente vinculado e o espaço profano remotamente vinculado ao sagrado (ROSENDAHL, 1999, p. 239).

Em primeiro lugar, o espaço profano é definido a partir do espaço sagrado. Como a escuridão é a ausência da luz, o espaço profano é a ausência do sagrado. Assim, quanto a localização o espaço profano encontra-se na frente ou ao redor do espaço sagrado, e relaciona-se com este de forma direta, indireta ou remotamente. 
Essa releitura do espaço sagrado converge em gênero com a definição de Eliade: "o sagrado revela a realidade absoluta" (2010, p. 33). A qual é perseguida diuturnamente pelo homem religioso, que sonha por estar no espaço sagrado. Como bem definiu Guimarães, o que é o sertão: “confusa e tumultuosa massa do mundo sensível, caos ilimitado de que só uma parte ínfima nos e dado conhecer, precisamente a que se avista ao longo das veredas, tênues canais de penetração e comunicação" $(2015$, p. 14). Sertão, intuível (profano); veredas, conhecível (sagrado).

Muito mais que a coesão durkheimiana, ou do carisma werberiano e da hierofania eliadeana, a geógrafa passa a valorizar um personagem dos bastidores do sagrado: o devoto, o homem religioso, o ser que crê. Para Rosendahl: "todo lugar sagrado contém em si mesmo um sentido de obrigação intrínseca. Ele não apenas encoraja a devoção, como a exige; não apenas induz à aceitação intelectual, como reforça o compromisso emocional do devoto" (2012, p. 26).

A tipologia, localização do espaço sagrado e as práticas do devoto, orquestrada por Rosendahl, são contribuições imprescindíveis para os estudos da geografia da religião. $\mathrm{Na}$ modernidade as análises historicistas (des)sacralizaram o espaço sagrado. $\mathrm{Na}$ contramão da história Rosendahl sacraliza o espaço profano e o transforma em espaço sagrado. O que existe é cosmos. Fora disso, bem distante, remotamente, há apenas o caos.

\section{E viu o homem que tudo era bom (à guisa de conclusão)}

A forma como compreendemos o espaço, tempo, sagrado, profano, gênero, quantidade e qualidade é algo que nos foi propiciado das experiências religiosas, advindas do tempo primordial, pelos nossos antepassados. Como afirma Durkheim: "quando analisamos metodicamente as crenças religiosas primitivas, encontramos, naturalmente, as principais dessas categorias. Nasceram da religião; são produto do pensamento religioso" (1989, p. 38).

Neste escrito tentamos analisar como esse entendimento foi sendo construído nas ciências sociais, pelas ideias de Durkheim e Weber; na história pelas contribuições de Mirceia Eliade e na geografia da religião pelas interpretações de Ronsedahl. A ideia de totemismo, maná, carisma, campo religioso, hierofania, teofanias e a dessacralização do espaço sagrado são conceitos que tem sustentado os estudos e pesquisas sobre as religiões nas instituições acadêmicas. Os 25 anos do NEPEC/UERJ é uma prova irrefutável dessa conquista. Apesar disso, na atualidade, estudar sobre religião e manifestar-se pertencente a uma religião é uma atitude subversiva nos espaços acadêmicos.

A definição do espaço sagrado ou profano, ou a dada diferenciação entre ambos é uma recorrência do mundo dessacralizado, no qual a ciência preponderou em detrimento as outras formas de conhecimento. Para o homem religioso, das sociedades arcaicas inexistia essa preocupação. "O desejo do homem religioso de viver no sagrado, equivale [...] viver num mundo real e eficiente, e não numa ilusão" (ELIADE, 2010, p. 
32). O sagrado é o real, o espaço conhecível. Fora dessa realidade apenas sobrevive o caos.

Frente ao mundo caótico, a permanência e imutabilidade da montanha garantiu a localização do homem religioso do espaço sagrado e do espaço profano. A partir daí a construção de centros totêmicos, altares religiosos, templos, igrejas catedrais e hierópolis passou a ser um desejo de materializar e centralizar o espaço o sagrado, e separá-lo por definitivo do espaço profano. Desta feita, o sagrado é posto no espaço onde, ontologicamente sempre esteve: acima, abaixo, à frente, ao redor, direta, indireta e remotamente ligado a existência do ser no mundo.

\section{Referências bibliográficas}

DURKHEIM, É. As formas elementares da vida religiosa: o sistema totêmico na Austrália. São Paulo: Paulus, 2008.

BELLA CIAO. Disponível em: 〈https://pt.wikipedia.org/wiki/Bella_ciao〉. Acesso em: 25 de ago. de 2018.

DONNE, M. J. Meditações 17 (poemas). Disponível In: <http://depositodelembrancas.blogspot.com/2010/03/meditacao-17-1624.html>. Acesso em nov. 2018.

ELIADE, M. História das crenças e das idéias religiosas: da Idade da Pedra aos Mistérios de Elêusis (Tomo 1). Das origens ao Judaísmo (Vol. 1). Rio de Janeiro: Zahar, 1983.

ELIADE, M. Observaciones metodológicas sobre el estúdio del simbolismo religioso. In: ELIADE, Mircea e KITAGAWA, Joseph. Metodologia de la historia de las religiones. Barcelona: Paidos Orientalia, 1986.

ELIADE, M. O mito do eterno retorno: arquétipos e repetição. Lisboa: Edições 70, 1988.

ELIADE, M. Imagens e símbolos: ensaios sobre o simbolismo mágico-religioso. São Paulo: Martins Fontes, 1991.

ELIADE, M. O Sagrado e o Profano: a essência das religiões. São Paulo; Editora WMF Martins Fontes, 2010.

LANDAU, B. Os manuscritos perdidos dos Reis Magos: um tesouro da Biblioteca do Vaticano finalmente revelado. São Paulo: Matrix, 2013.

ROHDEN, C. C. S. A camuflagem do sagrado e o mundo moderno: à luz do pensamento de Mircea Eliade. Porto Alegre: EDIPUCRS, 1998.

ROSA, J. G. Grande sertão: veredas. Rio de Janeiro: Nova Fronteira, 2015.

ROSENDAHL, Z. O espaço, o sagrado e o profano. In: ROSENDAHL, Z; CORRÊA, R. L. (orgs). Manifestações da cultura no espaço. Rio de Janeiro: EdUERJ, 1999. 
ROSENDAHL, Z. Geografia da religião: uma proposta temática. GEOUSP - Espaço e Tempo, São Paulo, N 11, pp.9-19, 2002.

ROSENDAHL, Z. Hierópolis: o sagrado e o urbano. Rio de Janeiro: EdUERJ, 2009.

ROSENDAHL, Z. Conferencia NEPEC: local onde fluem as ideias e se escreve sobre elas. In: ROSENDAHL, Z. (org.) Trilhas do sagrado. Rio de Janeiro: EdUERJ, 2010.

ROSENDAHL, Z. Primeiro a obrigação, depois a devoção: estratégias espaciais da Igreja Católica no Brasil de 1500 a 2005. Rio de Janeiro: EdUERJ, 2012.

ROSENDAHL, Z. Os caminhos da construção teórica: ratificando e exemplificando as relações entre espaço e religião. In ROSENDAHL, Z.; CORRÊA, R. L. (orgs.). Geografia cultural: uma ontologia. Vol II. Rio de Janeiro: EdUERJ, 2013.

ROSENDAHL, Z. Uma procissão na Geografia. Rio de Janeiro: EdUERJ, 2018.

WEBER, M. Ensaios de sociologia. Tradução de Waltensir Dutra. $5^{\text {a }}$ ed. Rio de Janeiro: LTC Editora, 1982.

WEBER, M. Economia e sociedade: fundamentos da sociologia compreensiva. Vol. 1. Tradução de Regis Barbosa e Karen Elsabe Barbosa. Brasília: Editora UnB, 2009.

WEBER, M. Sociologia das religiões. Tradução de Cláudio Rodrigues. $2^{\mathrm{a}}$ ed. São Paulo: Ícone, 2015.

Avacir Gomes dos Santos Silva

Pós-doutoranda em Geografia pela Universidade do Estado do Rio de Janeiro, sob a supervisão da Profa. Dra. Zeny Rosendahl. Doutora em Geografia, Universidade Federal de Goiás. Mestre em Geografia, Universidade Federal de Rondônia. Professora Adjunta, Universidade Federal de Rondônia Pesquisadora do NEPEC em Rede e Líder do Grupo de Estudos e Pesquisas de Espacialidades Amazônicas.

Av. Porto Alegre, 4811, Centro, cep: 76940000, Rolim de Moura, Rondônia E-mail: avacir.santos@unir.br 